\title{
Wood and Veneer Properties of Fast Growing Species from Batai, Eucalyptus and Kelampayan
}

\author{
Wan Mohd Nazri Wan Abdul Rahman, Muhammad Fitri Sa'ad, Suffian Misran, Nur Nazihan \\ Sofian, Nor Yuziah Mohd Yunus*
}

\begin{abstract}
Anatomical, physical, chemical and veneer properties of wood are important aspect that affect applicability of wood based product. This study is focused on three fast growing species of Batai (Paraserianthes falcataria), Eucalyptus (Eucalyptus pellita) and Kelampayan (Neolamarckia cadamba). All trees were cut into three height portion (bottom, middle and top) and wood disc samples are taken for anatomical, physical and chemical determination from each part of height. Meanwhile veneer properties were determined for veneer sheet after peeling and drying process. Eucalyptus shows the highest number of vessel for $16 \mathrm{~mm}^{2}$ area and near pith has higher frequency of vessel occurrence than near bark. The highest specific gravity for Batai, Eucalyptus and Kelampayan were found in bottom portion, followed by middle and top portion. Percentages of moisture content for this tree species is increased going from bottom to top portion. Cold and hot water, alcohol toluene, ash content and lignin content were found to have significant differences for top, middle and bottom of tree portion. The highest of percentage of veneer shrinkage was shown by Kelampayan veneer. Meanwhile, Batai veneer exhibited the lowest contact angle. As the conclusion, species and tree portions were found to be significantly affected for the anatomical, physical and chemical properties. For veneer analysis, species were found to affect veneer parameters. The results are of importance in order to optimize the production of plywood from fast growing species in Malaysia.

Index Terms-Fast growing species, Veneer properties, Wood properties
\end{abstract}

\section{INTRODUCTION}

Fast growing species with low density wood is a good candidate to sustain supply of raw material. In Malaysia, forest plantation programmed has been initiated in 2005 by Ministry of Plantation Industries and Commodities (MPIC). Eight selected species had been gazette for forest plantation in Malaysia namely; Rubberwood (Hevea brasiliensis),

Revised Manuscript Received on April 30, 2020.

* Correspondence Author

Wan Mohd Nazri Wan Abdul Rahman, Faculty of Applied Sciences, Universiti Teknologi MARA Pahang, 26400 Bandar Tun Razak, Malaysia, +60 19-931 7230, (e-mail: wmdnazri@gmail.com).

Muhammad Fitri Sa'ad, Faculty of Applied Sciences, Universit Teknologi MARA Shah Alam, 40450 Shah Alam, Malaysia, +60 14-921 5542, (e-mail: mfitrisaad@gmail.com).

Suffian Misran, Forest Research Institute Malaysia, 52109 Kepong, Malaysia, +60 13-399 7472, (e-mail: suffian@frim.gov.my).

Nur Nazihan Sofian, Faculty of Applied Sciences, Universiti Teknologi MARA Shah Alam, 40450 Shah Alam, Malaysia, +60 16-943 4138, (e-mail: nazihansofian@gmail.com).

Nor Yuziah Mohd Yunus*, Faculty of Applied Sciences, Universiti Teknologi MARA Pahang, 26400 Bandar Tun Razak, Malaysia, +60 19-326 1426, (e-mail: noryuziah@uitm.edu.my).

(C) The Authors. Published by Blue Eyes Intelligence Engineering and Sciences Publication (BEIESP). This is an open access article under the CC BY-NC-ND license (http://creativecommons.org/licenses/by-nc-nd/4.0/)
Acacia (Acacia spp.), Kelampayan (Neolamarckia cadamba), Sentang (Azadirachta excelsa), Binuang (Octomeles sumatrana), Khaya (Khaya ivorensis), Batai (Paraserianthes falcataria) and Jati (Tectona grandis) (MTIB, 2015). All species had a potential to reduce problems of raw material availability and potentially to rejuvenate wood industry in Malaysia.

Tree species of forest plantation with fast growth characteristic can be considered and commercialized to overcome shortage of supply materials. However, fast growth is normally associated with low density wood. According to Muhammad Fitri et al., (2018), light density Batai (230-320 $\mathrm{kg} / \mathrm{m}^{3}$ ) has potential to be used as core veneer of plywood construction. Meanwhile, Rahman et al., (2019) reported on Kelampayan wood density which ranges from $370-410 \mathrm{~kg} / \mathrm{m}^{3}$ and classify it as light hardwood species. Eucalyptus with density range of $400-750 \mathrm{~kg} / \mathrm{m}^{3}$ falls into the medium hardwood species category (Boland et al. 1991). The colouration of Batai (white to reddish), Eucalyptus (brown to reddish) and Kelampayan (yellowish) is suitable for wood product that have either bright or dark appearance such as block board, plywood and LVL (Nordahlia et al., 2014). Earlier work on these three species has shown potentials of utilization for sawn timber, furniture, plywood, block board, veneer and pulp (Ismail, 1995; Sorienegara, 1993). Optimization of preliminary work is necessary. The fundamental study of wood properties is the answer. Thus this study investigates the anatomical, physical, chemical and veneer properties of Batai, Eucalyptus and Kelampayan wood for plywood production.

\section{MATERIALS AND METHOD}

TABLE I. Batai, Eucalyptus and Kelampayan tree were felled from trial area plot in Jengka Pahang. The diameter for Batai and Eucalyptus bole were ranging between 30 to $35 \mathrm{~cm}$ and Kelampayan was 40 to $45 \mathrm{~cm}$. Disk log were taken from each different tree height portion (bottom, middle and top) from each species following the position shown in Figure 1. Meanwhile veneers were taken from each species after peeling process. The method for determination of vessels follows IAWA (1989) Standard. The vessel count was done for each portion and the portions were also further sub-divided to near bark and near pith. For specific gravity and moisture content measurement procedure was referred to BS 373:1957. For chemical analysis, wood samples were ground and screened through size 40 mesh.

Published By:

Blue Eyes Intelligence Engineering \& Sciences Publication 
The chemical analysis was done in accordance to TAPPI Standard: Cold Water (T 207 os-75), Hot Water (T 202 os-75), Alcohol Toluene Soluble (T 222 os-75) Ash Content (T 15 os-58) and Lignin Content (T 222 os-75). Meanwhile, veneer properties were also determined for wettability and contact angle.

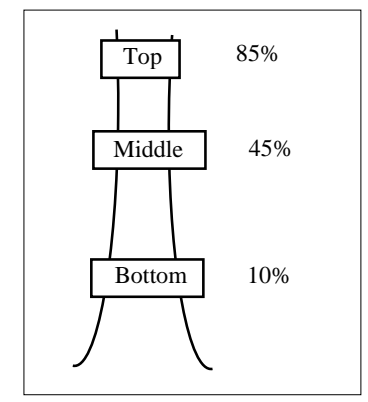

Figure 1: Height Portion of Tree

\section{RESULT AND DISCUSSION}

\section{A. Anatomical Properties}

Anatomical properties of this study was described based on numbers that observed inside wood which include vessels and pore. Table 1 showed average number of vessels according to species, tree portion (top, middle and bottom) and distance (near bark or near pith). Batai has lower number of vessels and bigger size because of the lower wood density as compared to Eucalyptus and Kelampayan (Plate 1). Lower density has bigger vessel size and contributes on small number of vessel (Bowyer et al, 1982). The result revealed number of vessel increased with denser of wood species and in near pith compared to near bark. Each species showed differing arrangement for various shapes of vessel. Batai showed large vessels large, in singular and cluster form with large distant between vessels. Eucalyptus exhibits smaller vessel size, majority singular and closely spaced. For Kelampayan the vessel are larger than Eucalyptus but smaller than Batai. The vessels are also distinctively presence largely in coupled formation with medium spacing between vessels.

Table 1: Average of Anatomical Properties

\begin{tabular}{|l|l|c|c|}
\hline Species & Tree Portion & \multicolumn{2}{|c|}{ Number of Vessels } \\
\cline { 3 - 4 } & & Near Pith & Near Bark \\
\hline Batai & Top & 4 & 3 \\
& Middle & 4 & 3 \\
& Bottom & 4 & 4 \\
& Average & $\mathbf{4}$ & $\mathbf{3}$ \\
\hline Eucalyptus & Top & 9 & 7 \\
& Middle & 9 & 7 \\
& Bottom & 10 & 8 \\
& Average & $\mathbf{9}$ & $\mathbf{7}$ \\
\hline Kelampayan & Top & 5 & 4 \\
& Middle & 6 & 4 \\
& Bottom & 6 & 5 \\
& Average & $\mathbf{5}$ & $\mathbf{4}$ \\
\hline
\end{tabular}

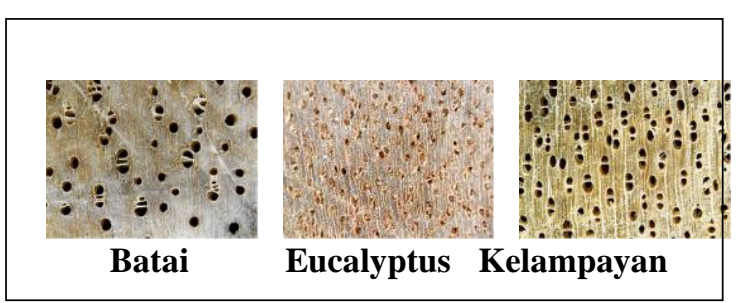

Retrieval Number: H0772044820//2020@BEIESP

DOI: 10.35940/ijmh.H0772.044820

Journal Website: www.ijmh.org
*Vessel in area $16 \mathrm{~mm}^{2}$

Plate 1: Vessel Shape and Distribution for Batai,

Eucalyptus and Kelampayan

The analysis of variance (ANOVA) on the effect of species and distance is shown in Table 2. Different of species and distance (near bark or near pith) were found to have highly significant effect on number of vessel present. The interaction of species and distance shows highly significant anatomical properties differences for number of vessel.

Table 2: The analysis of variance (ANOVA) on Number of Vessel

\begin{tabular}{|l|l|l|}
\hline SOV & Df & Number of Vessel \\
\hline Species & 2 & $196.74^{* *}$ \\
\hline Distance & 1 & $54.79^{* *}$ \\
\hline Species *Distance & 2 & $6.04 * *$ \\
\hline
\end{tabular}

Note: $\mathrm{SOV}=$ Source of variance, $\mathrm{Df}=$ Degree of freedom, $\mathrm{ns}=$ not significant at $\mathrm{p}<0.05$, $*=$ significant at $\mathrm{p}<0.05, * *=$ highly significant at $\mathrm{p}<0.01$

Table 3 shows the summary of DMRT for effect of species on anatomical properties. Eucalyptus has the highest number of vessel. The difference is significant at $p<0.05$. This could be related to the sample size vessels reducing air space in the wood. Air space reduction leads to higher wood content per unit volume thus leading to higher density of Eucalyptus. According to Zhang and Zhong (1992), different of specific gravity might have effect the anatomical properties of wood. TABLE II.

Table 3: Summary of DMRT on the Effect of Species on Number of Vessel

\begin{tabular}{|l|c|}
\hline Species & Number of Vessels $\left(16 \mathrm{~mm}^{2}\right)$ \\
\hline Batai & $3.63 \mathrm{c}$ \\
\hline Eucalyptus & $8.63 \mathrm{a}$ \\
\hline Kelampayan & $4.97 \mathrm{~b}$ \\
\hline
\end{tabular}

Note: Means with the same letter down the column are not significantly different at $\mathrm{p}<$ 0.05

Summary of T-Test on the effects of distance was shown in Table 4. The number of vessels was higher in near pith than near bark. This might be due to heartwood having higher percentage or frequency of vessels in near pith with smaller vessels size. The average occurrence of vessel were found to decreased from pith (heartwood) to bark (sapwood) and latewood had fewer vessels than early wood (Sousa, Louzada and Pereira, 2015).

Table 4: Summary of T-Test on the Effect of Distance on Number of Vessel

\begin{tabular}{|l|c|}
\multicolumn{2}{c}{ Number of Vessel } \\
\hline Distance & Number of Vessel \\
\hline Near Pith & $6.53 \mathrm{a}$ \\
\hline Near Bark & $4.96 \mathrm{~b}$ \\
\hline
\end{tabular}

Note: Means with the same letter down the column are not significantly different at $\mathrm{p}<$ 0.05

\section{B. Physical Properties}

Physical properties such as specific gravity and moisture content are main factors that have effect on the applicability of wood (Desch and Dinwoodie, 1996). Table 5 shows the average of specific gravity and moisture content according to species and tree portion. The results of specific gravity for Batai is $0.20 \mathrm{~g} / \mathrm{cm}^{3}$ (top) to $0.29 \mathrm{~g} / \mathrm{cm}^{3}$ (bottom), Eucalyptus is $0.57 \mathrm{~g} / \mathrm{cm}^{3}$ (top) to $0.70 \mathrm{~g} / \mathrm{cm}^{3}$ (bottom) and Kelampayan is $0.37 \mathrm{~g} / \mathrm{cm}^{3}$ (top) to 0.56 $\mathrm{g} / \mathrm{cm}^{3}$ (bottom).

Published By:

Blue Eyes Intelligence Engineering \& Sciences Publication

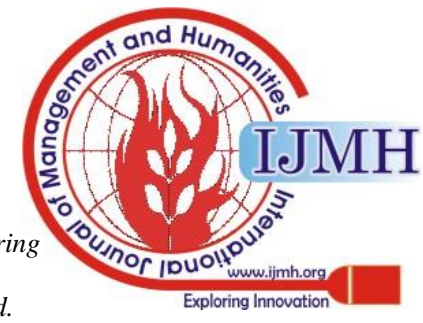


The specific gravity also increased moving from top to bottom following the position of tree portion for each species. For moisture content the trend of highest moisture at top portion, second highest in middle portion and lowest at bottom portion is seen in all three species. For top portion Kelampayan has the highest reading at $95.60 \%$, Eucalyptus second and Batai lowest at $75.45 \%$. Overall Batai showed lowest reading in all portion for specific gravity and moisture content.

Table 5: Average of Specific Gravity and Moisture Content

\begin{tabular}{|l|l|c|c|}
\hline Species & Tree Portion & Specific Gravity g/cm & Moisture Content \% \\
\hline Batai & Top & 0.20 & 75.45 \\
& Middle & 0.25 & 65.93 \\
& Bottom & 0.29 & 62.33 \\
& Average & $\mathbf{0 . 2 6}$ & $\mathbf{6 7 . 9 0}$ \\
\hline Eucalyptus & Top & 0.57 & 87.76 \\
& Middle & 0.65 & 84.74 \\
& Bottom & 0.70 & 84.31 \\
& Average & $\mathbf{0 . 6 4}$ & $\mathbf{8 5 . 6 0}$ \\
\hline Kelampayan & Top & 0.37 & 95.60 \\
& Middle & 0.46 & 88.04 \\
& Bottom & 0.56 & 81.39 \\
& Average & $\mathbf{0 . 4 6}$ & $\mathbf{8 8 . 3 4}$ \\
\hline
\end{tabular}

*Values are average of 10 samples

Table 6 shows the analysis of variance (ANOVA) on the effect of species and tree portion. Species and tree portion were found to significantly affect specific gravity and moisture content. The results have been anticipated as the vessel number, size and density per $16 \mathrm{~mm}^{2}$ for each species are significantly different.

Table 6: Summary of ANOVA on Physical Properties

\begin{tabular}{|l|l|l|l|}
\hline SOV & Df & $\begin{array}{l}\text { Specific } \\
\text { Gravity }\end{array}$ & $\begin{array}{l}\text { Moisture } \\
\text { Content }\end{array}$ \\
\hline Species & 2 & $775.22^{* *}$ & $31.71^{* *}$ \\
\hline Tree portion & 2 & $95.18^{* *}$ & $93.45^{* *}$ \\
\hline Species *Tree portion & 4 & $4.06^{* *}$ & $51.21^{* *}$ \\
\hline
\end{tabular}

Table 7 shows that specific gravity of Eucalyptus is the highest (significantly difference) compared to the other two species. According to Paes et al. (2015), the density of Eucalyptus spp. was around $0.57 \mathrm{~g} / \mathrm{cm}^{3}$. Based on MTIB Timber Classification (2010), specific gravity of Batai and Kelampayan can be classified as Light Hardwood while Eucalyptus classified as Medium Hardwood. The highest average moisture content was recorded by Kelampayan. The value is slightly lower to value reported by Faizah et al. (2014) at $97.86 \%$.

Table 7: Summary DMRT on the Effects of Species on Specific Gravity and Moisture Content

\begin{tabular}{|l|c|c|}
\hline Species & Specific Gravity & $\begin{array}{c}\text { Moisture } \\
\text { Content }\end{array}$ \\
\hline Batai & $0.25 \mathrm{c}$ & $67.90 \mathrm{~b}$ \\
\hline Eucalyptus & $0.64 \mathrm{a}$ & $85.60 \mathrm{a}$ \\
\hline Kelampayan & $0.46 \mathrm{~b}$ & $88.34 \mathrm{a}$ \\
\hline
\end{tabular}

Note: Means with the same letter down the column are not significantly different at $\mathrm{p}<$ 0.05

Specific gravity was observed highest in bottom portion of tree (Table 8). This might be due to bottom portion having thicker cell wall and contained large amount of heartwood that make it denser. As enhancement height of tree progress diminishing heartwood size occurs. Cell wall thickness is shown to strongly correlate with density of wood at height portion of tree (Sheree, et al., 2006).

Table 8: Summary DMRT on the Effects of Tree Portion on Specific Gravity and Moisture Content

\begin{tabular}{|l|l|l|}
\hline Tree Portion & Specific Gravity & Moisture Content \\
\hline Top & $0.38 \mathrm{c}$ & $86.27 \mathrm{a}$ \\
\hline Middle & $0.45 \mathrm{~b}$ & $79.57 \mathrm{~b}$ \\
\hline Bottom & $0.52 \mathrm{a}$ & $76.01 \mathrm{c}$ \\
\hline
\end{tabular}

Note: Means with the same letter down the column are not significantly different at $\mathrm{p}<$ 0.05

Meanwhile moisture content shows the highest with significant difference in top of tree portion. Percentage of moisture content is increase due to height of tree portion that contain more sapwood than heartwood in top portion, compared to bottom portion. Heartwood consist of dormant old cells that provide strength while sapwood contain active cells that gave top portion lesser density and fast growth rate (Bendtsen, 1978).

\section{Chemical Properties}

Chemical analysis of wood is the study on chemical composition in wood structure that gives effect on properties of wood composite product. Table 9 shows the average of chemical properties according to species and tree portion.

Table 9: Average of Chemical Properties of Batai, Eucalyptus and Kelampayan at different portion

\begin{tabular}{|l|l|l|l|l|l|l|}
\hline \multirow{3}{*}{ Species } & $\begin{array}{l}\text { Tree } \\
\text { Portion }\end{array}$ & $\begin{array}{l}\text { Cold } \\
\text { Water } \\
(\%)\end{array}$ & $\begin{array}{l}\text { Hot } \\
\text { Water } \\
(\%)\end{array}$ & $\begin{array}{l}\text { Alcohol } \\
\text { Toluene } \\
(\%)\end{array}$ & $\begin{array}{l}\text { Ash } \\
\text { Content } \\
(\%)\end{array}$ & $\begin{array}{l}\text { Lignin } \\
\text { Content } \\
(\%)\end{array}$ \\
\hline \multirow{2}{*}{ Batai } & Top & 4.08 & 4.59 & 2.35 & 0.92 & 26.92 \\
& Middle & 4.77 & 4.68 & 2.44 & 0.89 & 28.23 \\
& Bottom & 4.61 & 4.92 & 3.05 & 0.94 & 27.72 \\
& Average & $\mathbf{4 . 4 9}$ & $\mathbf{4 . 7 3}$ & $\mathbf{2 . 6 1}$ & $\mathbf{0 . 9 2}$ & $\mathbf{2 7 . 6 2}$ \\
\hline Eucalyptus & Top & 5.38 & 6.11 & 3.32 & 0.46 & 33.50 \\
& Middle & 5.52 & 6.18 & 3.36 & 0.53 & 31.83 \\
& Bottom & 5.15 & 7.01 & 3.49 & 0.60 & 35.13 \\
& Average & $\mathbf{5 . 3 5}$ & $\mathbf{6 . 4 3}$ & $\mathbf{3 . 3 9}$ & $\mathbf{0 . 5 3}$ & $\mathbf{3 3 . 4 9}$ \\
\hline Kelampayan & Top & 6.66 & 7.95 & 3.60 & 0.52 & 32.77 \\
& Middle & 7.74 & 7.53 & 3.97 & 0.60 & 37.82 \\
& Bottom & 7.44 & 8.76 & 4.23 & 0.68 & 30.86 \\
& Average & $\mathbf{7 . 2 8}$ & $\mathbf{8 . 0 8}$ & $\mathbf{3 . 9 3}$ & $\mathbf{0 . 6 0}$ & $\mathbf{3 3 . 8 1}$ \\
\hline
\end{tabular}

\section{i. Cold Water and Hot Water Soluble}

Table 9 shows results cold and hot water for Batai, Eucalyptus and Kelampayan according to tree portion. This result is important in evaluation of water soluble extracts such as starch, sugar, tannin and phenolic compound within any lignocellulosic material (Jamaludin, 2006). The highest cold water for Batai is 4.77 (middle) and the lowest is 4.08 (top) and the highest for Kelampayan is 7.74 (middle) and the lowest is 6.66 (top).

Meanwhile the highest for Eucalyptus is 5.52 (middle) and the lowest is 5.15 (bottom).

For hot water, the highest result for Batai is 4.92 (middle) and the lowest is 4.59 (top), Eucalyptus highest with 7.01 (bottom) and lowest is 6.11 (top) and highest of Kelampayan is 8.76 (bottom) and lowest is 7.53 (middle). This difference solubility was caused by hydrolysis and corresponding to the increase in solubility of wood substance during boiling process (Hawley et al, 1924). Kelampayan shows the highest of cold and hot water solubles (Table 11).

\section{and $\mathrm{Hu}$}

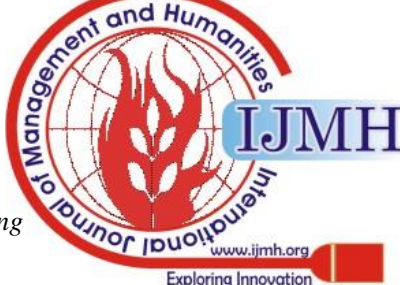


Table 10: Summary of ANOVA on Chemical Properties

\begin{tabular}{|l|c|c|c|c|c|}
\hline SOV & $\begin{array}{c}\text { Cold } \\
\text { Water }\end{array}$ & Hot Water & $\begin{array}{c}\text { Alcohol } \\
\text { Toluene }\end{array}$ & $\begin{array}{c}\text { Ash } \\
\text { Content }\end{array}$ & $\begin{array}{c}\text { Lignin } \\
\text { Content }\end{array}$ \\
\hline Species & $197.35^{* *}$ & $200.64^{* *}$ & $642.64^{* *}$ & $89.80^{* *}$ & $22.64^{* *}$ \\
\hline Tree Portion & $9.17^{* *}$ & $12.48^{* *}$ & $101.97^{* *}$ & $6.64^{* *}$ & $1.32 \mathrm{~ns}$ \\
\hline $\begin{array}{l}\text { Species *Tree } \\
\text { Portion }\end{array}$ & $2.67^{*}$ & $1.68 \mathrm{~ns}$ & $12.45^{* *}$ & $0.89 \mathrm{~ns}$ & $4.33^{* *}$ \\
\hline
\end{tabular}

Table 11: Summary DMRT on the Effects of Species on Chemical Properties

\begin{tabular}{|l|l|l|l|l|l|}
\hline Species & $\begin{array}{l}\text { Cold } \\
\text { Water }\end{array}$ & $\begin{array}{l}\text { Hot } \\
\text { Water }\end{array}$ & $\begin{array}{l}\text { Alcohol } \\
\text { Toluene }\end{array}$ & $\begin{array}{l}\text { Ash } \\
\text { Content }\end{array}$ & $\begin{array}{l}\text { Lignin } \\
\text { Content }\end{array}$ \\
\hline Batai & $4.48 \mathrm{c}$ & $4.73 \mathrm{c}$ & $2.61 \mathrm{c}$ & $0.91 \mathrm{a}$ & $27.64 \mathrm{~b}$ \\
\hline Eucalyptus & $5.35 \mathrm{~b}$ & $6.43 \mathrm{~b}$ & $3.40 \mathrm{~b}$ & $0.53 \mathrm{c}$ & $33.49 \mathrm{a}$ \\
\hline Kelampayan & $7.32 \mathrm{a}$ & $8.08 \mathrm{a}$ & $3.93 \mathrm{a}$ & $0.59 \mathrm{~b}$ & $33.81 \mathrm{a}$ \\
\hline
\end{tabular}

Note: Means with the same letter down the column are not significantly different at $\mathrm{p}$ 0.05

\section{ii. Alcohol Toluene Soluble}

From Table 9, the highest alcohol toluene soluble content for Batai is 3.05 (bottom) and the lowest is 2.35 (top) and the highest for Kelampayan is 4.23 (bottom) and the lowest is 3.60 (top). Meanwhile the highest for Eucalyptus is 3.49 (bottom) and the lowest is 3.32 (top). Summarized DMRT showed bottom tree portion was the highest with significant different, followed by decreased for the middle to top of tree portion (Table 12). Extractive content in heartwood is important for fungal resistance (Taylor et al, 2002). It may slightly increase weight of wood and lowers moisture conditions (Miller, 1999). According to Tohmura (1998), extractive have shown to interfere with the cure of phenolic resin systems used in manufacture of wood composite. Table 11 shows Kelampayan having the highest with significant different than the other two species. on Chemical Properties

\begin{tabular}{|l|l|l|l|l|l|}
\hline $\begin{array}{l}\text { Tree } \\
\text { Portion }\end{array}$ & $\begin{array}{l}\text { Cold } \\
\text { Water }\end{array}$ & $\begin{array}{l}\text { Hot } \\
\text { Water }\end{array}$ & $\begin{array}{l}\text { Alcohol } \\
\text { Toluene }\end{array}$ & $\begin{array}{l}\text { Ash } \\
\text { Content }\end{array}$ & $\begin{array}{l}\text { Lignin } \\
\text { Content }\end{array}$ \\
\hline Top & $5.39 \mathrm{~b}$ & $6.22 \mathrm{~b}$ & $3.08 \mathrm{c}$ & $0.62 \mathrm{~b}$ & $31.14 \mathrm{a}$ \\
\hline Middle & $6.01 \mathrm{a}$ & $6.13 \mathrm{~b}$ & $3.27 \mathrm{~b}$ & $0.68 \mathrm{ab}$ & $32.62 \mathrm{a}$ \\
\hline Bottom & $5.76 \mathrm{a}$ & $6.90 \mathrm{a}$ & $3.60 \mathrm{a}$ & $0.73 \mathrm{a}$ & $31.19 \mathrm{a}$ \\
\hline
\end{tabular}

Note: Means with the same letter down the column are not significantly different at $\mathrm{p}<$ 0.05

\section{iii. Ash Content}

AS seen in Table 9, the highest ash content for Batai is 0.94 (bottom) and the lowest is 0.89 (middle) and the highest for Eucalyptus is 0.60 (bottom) and the lowest is top (0.46). The highest ash content for Kelampayan is 0.68 (bottom) and the lowest is 0.52 (top). Bottom of tree portion has more heartwood and higher density, thus increased the percentage of ash content. Jenskins et al. (1995), reported that ash content is primarily silica and is seen more in heartwood.

Lignin is incrusting material forming part of cell wall and middle lamella of wood that can be removed by process of pulping and bleaching. Table 9 shows average lignin content for Batai, Eucalyptus and Kelampayan according to tree portion. The highest for Batai is 28.23 (middle) and the lowest is 26.92 (top) and the highest for Kelampayan is 37.82 (middle) and the lowest is 30.86 (bottom). Meanwhile the highest for Eucalyptus is 35.13 (bottom) and the lowest is 31.83 (middle). Higher lignin content will increase the
Table 12: Summary DMRT on the Effects of Tree Portion

\section{iv. Lignin Content}

stiffness of wood in cell wall. It is associated to support for plant organs in order to increased growth in height (Boudet, 2000).

\section{Veneer properties}

The veneer shrinkage and veneer wettability are factors that can affect strength and bonding of plywood. Different wood density will present variable veneer shrinkage. The veneer shrinkage and smoothness can be affected by the wood density. Surface smoothness and roughness will have an impact on the wettability or veneers. The veneer density will also have impact on wettability in term of the ease in adhesive penetration during glue spread. This will affect the veneers bonded properties. Thus, some observation on veneer was important for this study as to correlate the effect of veneer properties.

\section{i. Veneer shrinkage}

In general, wood is an anisotropic material that has different directional properties in tangential, radial and longitudinal, which affect its apparent mechanical properties (Bodig and Jayne, 1982). According to Ogata, Fujita, Nobuchi, and Sahri (2003), wood grains represent the orientation of axial and grain angle which refers to tangential and longitudinal plane. When wood is dried, moisture is removed and shrinkage of shape occurs. However, shrinkage of wood is not the same in all three directions. According to Irle and Barbu (2010), typically relative movement ratio between the three direction is approximately 20:21:1 (tangential: radial: longitudinal), respectively. Table 13 shows average percentage of veneer shrinkage by species.

\section{Table 13: Average percentage of veneer shrinkage by} Batai, Eucalyptus and Kelampayan.

\begin{tabular}{|l|c|c|c|}
\hline \multirow{2}{*}{ Veneer Direction } & \multicolumn{3}{|c|}{ Species } \\
\cline { 2 - 4 } & Batai & Eucalyptus & Kelampayan \\
\hline Tangential (\%) & 4.63 & 7.45 & 5.93 \\
\hline Radial (\%) & 1.92 & 0.90 & 3.52 \\
\hline Longitudinal (\%) & 0.62 & 0.43 & 0.56 \\
\hline
\end{tabular}

Note: Percentage of shrinkage after drying until $8 \%$ of moisture conten

The analysis of variance (ANOVA) of the effect of species and veneer direction are showed in Table 14. Species and veneer direction were found to significantly affect the shrinkage. Interaction between species and veneer direction also shows a significant effect on veneer shrinkage.

Table 14: The Analysis of Variance (ANOVA) on Veneer Shrinkage

\begin{tabular}{|l|c|l|}
\hline SOV & Df & Shrinkage \\
\hline Species & 2 & $948.27^{*}$ \\
\hline Veneer Direction & 2 & $35051.98^{*}$ \\
\hline Species *Veneer Direction & 4 & $2310.43^{*}$ \\
\hline
\end{tabular}

Note: $\mathrm{SOV}=$ Source of variance, $\mathrm{Df}=$ Degree of freedom, $\mathrm{ns}=$ not significant at $\mathrm{p}<0.05$, $*=$ significant at $\mathrm{p}<0.05, * *=$ highly significant at $\mathrm{p}<0.01$

The summary of DMRT for effects of veneer shrinkage on different species is shown in Table 15. There is significance difference between species on veneer shrinkage. Neolamarckia cadamba had the highest value and significantly different to the other species. This might be due to Neolamarckia cadamba had higher moisture content (Table 7).

Published By:

Blue Eyes Intelligence Engineering \& Sciences Publication 
According to Lunguleasa (2013), there are some chemical changes and modification in the cell wall during drying process that play role in wood hygroscopy. Higher moisture content may cause more shrinkage when the moisture content is decreased (Fengyan, Xiaoshan, Lei, and Chun, 2010).

\section{Table 15: Summary DMRT on the Effects of Species}

\begin{tabular}{|l|c|}
\hline Species & Veneer Shrinkage \\
\hline Batai & $2.40 \mathrm{c}$ \\
\hline Eucalyptus & $2.93 \mathrm{~b}$ \\
\hline Kelampayan & $3.31 \mathrm{a}$ \\
\hline
\end{tabular}

Note: Means with the same letter down the column are not significantly different at $\mathrm{p}<$ 0.05

Veneer shrinkage on the tangential direction is highest and significantly different compared to radial and longitudinal direction as shown in Table 16. Radial shrinkage is usually less than tangential shrinkage (about $50 \%$ ) due to effect of fibre direction properties; while longitudinal shrinkage is so slight as compared to other direction (Lunguleasa, 2013).

\section{Table 16: Summary DMRT on the Effects of Veneer} Direction on Veneer Shringkage

\begin{tabular}{|l|c|}
\hline Veneer Direction & Veneer Shrinkage \\
\hline Longitudinal & $0.54 \mathrm{c}$ \\
\hline Radial & $2.13 \mathrm{~b}$ \\
\hline Tangential & $5.97 \mathrm{a}$ \\
\hline
\end{tabular}

Note: Means with the same letter down the column are not significantly different at $\mathrm{p}$ 0.05

\section{ii. Veneer wettability}

According to Gardner, Generalla, Gunnells, and Wolcott (1991), wettability of the wood can be identified by various methods such as contact angle, surface scanned micro-droplets and predicted values. Previously, the contact angle method was commonly used to investigate surface characteristic of wood and wood based composites (Ayrilmis, Dundar, Candan, and Akbulut, 2009). Table 17 shows average angle droplets of melamine urea formaldehyde (MUF) adhesive on different surface and measured over a different contact time.

Table 17: Average of Contact Angle According to Time

\begin{tabular}{|c|c|c|c|c|c|c|}
\hline \multirow[b]{2}{*}{ Species } & \multirow{2}{*}{$\begin{array}{l}\text { Veneer } \\
\text { Surface }\end{array}$} & \multicolumn{5}{|c|}{ Wet Time $/{ }^{0}$ Angle } \\
\hline & & $\begin{array}{c}5 \\
\text { second }\end{array}$ & $\begin{array}{c}5 \\
\text { minute }\end{array}$ & $\begin{array}{c}12 \\
\text { minute }\end{array}$ & $\begin{array}{c}20 \\
\text { minute }\end{array}$ & $\begin{array}{c}50 \\
\text { minute }\end{array}$ \\
\hline \multirow{2}{*}{ Batai } & Tight & $78^{0}$ & $68^{0}$ & $63^{0}$ & $55^{0}$ & $48^{0}$ \\
\hline & Loose & $67^{0}$ & $62^{0}$ & $53^{0}$ & $48^{0}$ & $38^{0}$ \\
\hline \multirow{2}{*}{ Eucalyptus } & Tight & $72^{0}$ & $43^{0}$ & $33^{0}$ & $23^{0}$ & $13^{0}$ \\
\hline & Loose & $63^{0}$ & $37^{0}$ & $27^{0}$ & $15^{0}$ & $7^{0}$ \\
\hline \multirow{2}{*}{ Kelampayan } & Tight & $62^{0}$ & $52^{0}$ & $38^{0}$ & $20^{\circ}$ & $13^{0}$ \\
\hline & Loose & $58^{0}$ & $47^{0}$ & $33^{0}$ & $17^{0}$ & $12^{0}$ \\
\hline
\end{tabular}

The analysis of variance (ANOVA) of the effect of species, veneer surface and time are showed in Table 18. Species, veneer surface and time were observed to affect the contact angle significantly. Interaction between species, veneer surface and time also shows a significant effect on contact angle.

Table 18: The Analysis of Variance (ANOVA) on Wettability

\begin{tabular}{|l|c|c|}
\hline SOV & Df & Contact Angle \\
\hline Species & 2 & $5884.40^{*}$ \\
\hline Veneer Surface & 1 & $974.27^{*}$ \\
\hline
\end{tabular}

\begin{tabular}{|l|c|c|}
\hline Time & 4 & $6089.44 *$ \\
\hline Species *Veneer Surface & 2 & $65.29 *$ \\
\hline Species *Time & 8 & $422.68 *$ \\
\hline Veneer Surface *Time & 4 & $7.02 *$ \\
\hline $\begin{array}{l}\text { Species *Time *Veneer } \\
\text { Surface }\end{array}$ & 8 & $7.29 *$ \\
\hline
\end{tabular}

Note: $\mathrm{SOV}=$ Source of variance, $\mathrm{Df}=$ Degree of freedom, ns $=$ not significant at $\mathrm{p}<0.05$, $*=$ significant at $\mathrm{p}<0.05, * *=$ highly significant at $\mathrm{p}<0.01$

Table 19 showed the summary of DMRT effects of species on veneer surface using MUF adhesive. All three species were observed to have significant differences in contact angle due to differences in veneer properties and density. Eucalyptus pellita shows the highest value and are significantly different than the other species. Hardwoods have substantially higher contents of hemicelluloses in comparison with softwoods and hemicellulose is one of the factors that have an effect on wettability.

Table 19: Summary DMRT on the Effects of Species on Contact Angle

\begin{tabular}{|l|c|}
\hline Species & Contact Angle \\
\hline Batai & $33.43 \mathrm{c}$ \\
\hline Eucalyptus & $57.82 \mathrm{a}$ \\
\hline Kelampayan & $35.34 \mathrm{~b}$ \\
\hline
\end{tabular}

Note: Means with the same letter down the column are not significantly different at $\mathrm{p}<$ 0.05

Veneer surface with high contents of extractive and lignin were found to have higher contact angles (Jaic et al., 1996). According to Mantanis and Young (1997), the higher extractive contents can lead to lower the wood wettability by water. Table 20 shows the summary of T-Test on the effects of tight and loose surface. It is observed that tight surface is higher than loose surface for contact angle. This might be due to loose surface that had check tension that was affected by knives on the peeling lathe process and make it easier for liquid to wet and penetrate into veneer check surface.

\section{Table 20: T-Test Effects of Species on Veneer Surface}

\begin{tabular}{|l|c|}
\hline Veneer Surface & Contact Angle \\
\hline Tight & $45.36 \mathrm{a}$ \\
\hline Loose & $38.97 \mathrm{~b}$ \\
\hline
\end{tabular}

Note: Means with the same letter down the column are not significantly different at $\mathrm{p}$ 0.05

Table 21 shows that time significantly affect the contact angle. As the liquid was measured for contact angle from 5 second to 50 minute, increase of time decreases the contact angle of liquid due to the penetration or spreading of glue on the veneer surface.

The presence of hydroxyl group on the veneers will attract the moisture in MUF resin causing spreading of liquid. The pores size and distance of the species will also encourage the spreading or wetting of veneers. For all three species the loose side for veneer surface shows faster and better wetting. According to Nussbaum (1999), contact angles and the wetting is influenced by direction of fibre on the surface. Veneer that have good wetting improves the bonding strength in wood composite product such as plywood and laminated veneer lumber (LVL).

Published By:

Blue Eyes Intelligence Engineering \& Sciences Publication

(C) Copyright: All rights reserved.

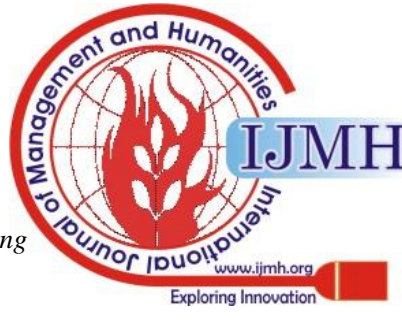


Table 21: T-Test Effects of Time on Contact Angle

\begin{tabular}{|c|c|}
\hline Time & Contact Angle \\
\hline 5 second & $66.76 \mathrm{a}$ \\
\hline 5 minute & $51.63 \mathrm{~b}$ \\
\hline 12 minute & $41.20 \mathrm{c}$ \\
\hline 20 minute & $29.57 \mathrm{~d}$ \\
\hline 50 minute & $21.27 \mathrm{e}$ \\
\hline
\end{tabular}

Note: Means with the same letter down the column are not significantly different at $\mathrm{p}$ 0.05

\section{CONCLUSION}

TABLE III. For anatomical properties, increase number of vessel was observed in highest wood density species which is Eucalyptus. Tree height portion has highly significant effect on specific gravity of Batai, Eucalyptus and Kelampayan. Wood moisture content shows highly significant to Batai and Kelampayan for wood portion, but has no significantly effect to Eucalyptus. The chemical properties of Batai, Eucalyptus and Kelampayan were analyzed for cold and hot water, alcohol toluene, ash content and lignin content showing big variation in the cold and hot water soluble content for the species. For veneer properties, increased shrinkage was observed in higher density of wood species. The denser wood species possessed high wettability which was observed by contact angle method. As the conclusion, species and tree portion were found to significantly affect the anatomical, physical and chemical properties. For veneer analysis, species were found to affect veneer parameters.

\section{ACKNOWLEDGMENT}

The authors gratefully acknowledged 600-RMI/FRGS 5/3 (263/2019) for funding the work.

\section{REFERENCES}

1. Aydin I \& Colakoglu G. (2008). Variations in bending strength and modulus of elasticity of spruce and alder plywood after steaming and high temperature drying. Mechanic of Advanced Materials and Structures 15 (5). 371-374.W.-K. Chen, Linear Networks and Systems (Book style). Belmont, CA: Wadsworth, 1993, pp. 123-135.

2. Ayrilmis, N., Dundar, T., Candan, Z., \& Akbulut, T. (2009). Wettability of fire retardant treated laminated veneer lumber (LVL) manufactured from veneers dried at different temperatures. Bioresources 4, pp 1535 - 1543.

3. Bal BC \& Bektas I. (2012). The effects of wood species, load direction and adhesives on bending properties of laminated veneer lumber. Bioresources 7 (3): 3104-3112

4. Bendsten B. A., (1978). Properties of wood from improved and managed trees. Forest Product Journal, 28 (10), 61-72pp

5. Bodig, J., \& Jayne, B. A. (1982). Mechanics of wood and wood composites.Van Nostrand Reinhold, New York.

6. Boland, D. J., Brophy, J. J., \& House, A. P. N. (1991). Eucalyptus leaf, oils, use, chemistry, distillation and marketing. Inkata Press, Melbourne.

7. Boudet M., (2000). Lignin and lignification: selected issues. Plants Physiol. Biochem., 38, 81-96.

8. Bowyer J. L., Shmulsky R. and Haygreen J. G., (1982). Forest products and wood science. An introduction. Fourth Edition 2003. Iowa State Press. A Blackwell Publishing Company.

9. BS 373: (1957). Method of Testing Small Specimen of Timber

10. Cai Z. (2006). Selected properties of MDF and flakeboard overlaid with fiberglass mats. Forest Product Journal. 56(11/12): 142-146.

11. Cai Z \& Ross RJ. (2010). Mechanical properties of wood-based composite materials. Forest Products Laboratory: 12-1 - 12-12.

12. Desch, H. E. \& Dinwoodie, J. M. (1996). Timber structure, properties, conversion and use. $7^{\text {th }}$ ed. London, UK: Macmillan Press. p 306

13. Faizah, A. L., Sakinah, M. T., \& Jamaludin, K. (2014). Physical and chemical properties of kelampayan (Neolamarckia cadamba) wood. $215-218$.

14. Fengyan, P., Xiaoshan, H., Lei, L. \& Chun, M. (2010). Effect of temperature on the antential shrinkage coefficient of small-diameter International Journal of Latest Research $n$ Science and Technology. pp

polygonal cutting of Larix gmelinii Rupr, Conference: Logistic System and Intelligent Management, pp 1945-1948.

15. Gardner, D. J., Generalla, N. C., Gunnells, D. W., \& Wolcott, M. C. (1991). Dynamic wetting of wood. Langmuir 7, pp 2498 - 2502.

16. Hawley L. F., Fleck L. C. and Richard C.A., (1924). The relation between durability and chemical composition in wood. Ind. Eng. Chem. 16(7), 699-700

17. International Association of Wood Anatomist (IAWA) (1989). List of microscopic features for hardwood identification, No. 10 (3), 219-232.

18. Irle, M., \& Barbu, M. C. (2010). Wood-Based Panels Technology. An Introduction for Specialists. Brunel University Press, pp 1-4, 74-85.

19. Ismail J., Jusoh M. Z. and Sabri H. M., (1995). Anatomical variation of lesser known commercial timbers in Peninsular Malaysia. Forest Research Institute Malaysia 32. 139-258.

20. Jaic, M., Ivanovic, R. Z., Stevanoniv, T., \& Dekanski, A. (1996). Comparison of surface properties of Beech and Oak wood as determined by ESCA method. Holz Roh- Werkstoff 54, pp 47 - 41.

21. Jamaludin K., (2006). Properties of particleboard and thermoplastic board from buluh semantan. University Publication Centre (UPENA).

22. Lunguleasa, A. (2013). The influence of temperature on the shrinkage of white poplar veneers. Faculty of Wood Engineering, Romania. pp 450-455.

23. Mantanis, G. I., \& Young, R. A. (1997). Wetting of wood. Wood Sci. and Technol. pp 32, 339 - 353

24. Malaysia Timber Industry Board, MTIB. (2015). Export of Major Timber Product Malaysia 2015. Kuala Lumpur.

25. Muhammad-Fitri, S., Suffian, M., Wan-Mohd-Nazri, W.A.R., Nor-Yuziah, Y. (2018). Mechanical properties of plywood from batai (paraserianthes falcataria), Eucalyptus (Eucalyptus Pellita) and Kelempayan (neolamarckla cadamba) with different layer and species arrangement. Journal of Tropical Forest Science. Vol. 30 (1). pp 58-66.

26. Miller R. B. (1999). Structure of wood. Chapter 2. Wood handbook Forest Product Laboratory. U.S. Department of Agriculture.

27. Nordahlia, A. S., Lim, S. C., Hamdan, H., \& Anwar. (2014). Wood properties of selected plantation species: Tectona grandis, Neolamarckia cadamba, Octomeles sumatrana and Paraserianthes falcataria. Technology bulletin. ISSN: 139-258. FRIM, p 3.

28. Nussbaum, R. M. (1999). Natural surface inactivation of Scots pine and Norways spruce evaluated by contact angle measurements. Holz Roh - Werkstoff 57, pp 419 - 424.

29. Ogata, Y., Fujita, M., Nobuchi, T., \& Sahri M. H. (2003). Macroscopic and anatomical investigation of interlocked grain in Acacia mangium. IAWA J 24: pp 13 - 26.

30. Paes, J.B., Brocco, V.F., Moulin, J.C., Motta, J.P., \& Alves, R.C. (2015). Effect of extractives and density on natural resistance of woods to termite Nasutitermes corniger. Scielo, Cerne. ISSN 0104-7760. Pp $1 / 11-9 / 11$.

31. Pavlo B. Salim H. Olga P \& Jan S. (2009). Shear strength of exterior plywood panels pressed at low temperature. Materials. 2, 876-882.

32. Rahman, W.M.N., Sajali, N.A., Yunus, N.Y.M. (2019). Screw withdrawal properties of Kelampayan and Sesendok Glue-laminated timber. International Journal of Engineering and Advanced Technology. Vol 9, Issue 1, pp 5952-5956.

33. Sheree C., Lisa M., Lloyd D., Thomas R., Craig E. and Richard G., (2006). Wood formation from the base to the crown in Pinus radiate; gradients of tracheid wall thickness, wood density, radial growth rate and gene expression. Plant Molecular Biology, 60:pp 565-581.

34. Soerianegara I. and Lemmens R.H.M.J., (1993). Plant resources of South East Asia 5(1). Timber trees: major commercial timbers. Pudoc Scientific Publishers.

35. Sousa, V. B., Louzada, J. L., \& Pereira, H. (2015). Earlywood vessel features in Quercus faginea: relationship between ring width and wood density at two sites in Portugal. Italian Society of Silviculture and Forest Ecology. pp 5-6.

36. TAPPI (1978). TAPPI Official testing procedure. Technical Association of Pulp and Paper Industry. 220p

37. Taylor A M., Gartner B. L. and Morrell, (2002). Heartwood formation and natural durability. Wood and Fiber Science, 34, 587-611.

38. Tohmura S. (1998). Acceleration of the cure of phenolic resin adhesives VII: influence of extractive of merbau wood bonding. $J$. Wood Sci., 44, 211-216.

39. Zhang, B.J., \& Zhong, Y. (1992). Structure property relationship of wood in East liaoning oak. Wood Science of Technology 26. Pp $139-$ 149.

Published By:

Blue Eyes Intelligence Engineering

\& Sciences Publication

DOI: 10.35940/ijmh.H0772.044820

Journal Website: www.ijmh.org 


\section{AUTHOR PROFILE}

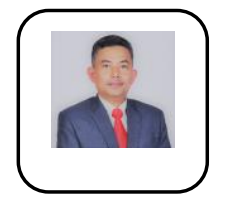

Wan Mohd Nazri Wan Abdul Rahman, is an associate professor at the Department of Wood Industry, Faculty of Applied Sciences, Universiti Teknologi MARA (UiTM), Pahang, Malaysia. He started teaching at UiTM since 2000. He obtained his Bachelor of Science (Forestry) Degree in 1998 and Master Degree of Science (Wood Utilization) in 2000 at Universiti Putra Malaysia (UPM). He holds a Philosophy Degree in 2009 from UiTM. His research fields in forest plantation, biomass and wood composite.

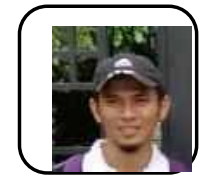

Muhammad Fitri Sa'ad, completed his study in Master of Science (Wood Science and Technology) in Universiti Teknologi MARA (UiTM) Shah Alam, Selangor Malaysia. He is a holder in Bachelor in Science (Hons.) Furniture Technology and Diploma in Wood Industry from UiTM.

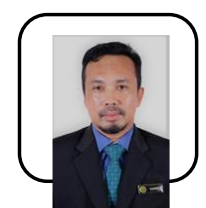

Suffian Misran, is a Senior Research Officer at the Forest Products Division, Forest Research Institute Malaysia. He obtained his first degree in Bachelor of Science (Hons) in industrial chemistry in 1996 and Master of Science degree in wood science in 2005 from Universiti Putra Malaysia. He completed is doctoral degree in wood science in 2011 from Bangor University, UK. He is a registered chemist and radiation safety officer, and lead an accredited testing laboratory. He is active in national committees for test standard development. He has led various research projects. His research interests are related to bio-composites, wood-based panels and thermoset adhesives.

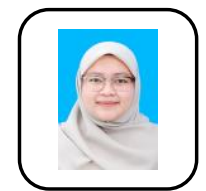

Nur Nazihan Sofian, is pursuing her study in Master of Science (Wood Science and Technology) in Universiti Teknologi MARA (UiTM) Shah Alam, Selangor, Malaysia. She is a holder in Bachelor in Science (Hons.) Furniture Technology and Diploma in Wood Industry from UiTM.

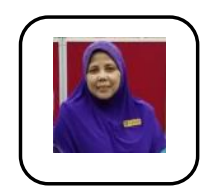

Nor Yuziah Mohd Yunus, is an associate professor at Department of Wood Industry, Faculty of Applied Sciences, Universiti Teknologi MARA (UiTM), Pahang, Malaysia. She started at UiTM since 2014. Before joining the academia, she was attached to Malayan Adhesives Chemicals (M) Sdn. Bhd. for 25 years working in the capacity of R\&D Manager and Director. She is a chemist by profession and her research fields include adhesive and wood composite. She has a Bachelor in Science from Monash University, Australia, MBA from Ohio University, USA and Doctorate from Universiti Putra Malaysia. 